\title{
Ömer Faruk Akün (1926-2016)
}

5 Nisan 1926'da Fatma İrfan Hanım ile Mehmed Ziyaeddin Bey'in oğlu olarak İstanbul'da dünyaya gelen Ömer Faruk Akün, Beşiktaş-Akaretler'de 38. İlkokul'da başladığı ilk öğrenimini Sultanahmet'te 44. İlkokul ile Beylerbeyi 27. İlkokulu’nda tamamladı (1936). Daha sonra önce orta kısmına kaydolduğu Kabataş Erkek Lisesi’nden mezun oldu (1943). Burada devrin tanınmış şairlerinden Zeki Ömer Defne, Faruk Nafiz Çamlıbel ve Nihad Sâmi Banarlı değişik sınıflarda hocası oldu. Yüksek tahsilini İstanbul Üniversitesi Edebiyat Fakültesi Türk Dili ve Edebiyatı Bölümü’nde, "Dede Korkut Hikâyelerinde Kompozisyon ve Tasvir” konulu teziyle tamamladı (1947). 1947-1948 yıllarında askerlik görevini ifa etti. 1951 yılında mezun olduğu bölüme, Ahmet Hamdi Tanpınar’ın başında bulunduğu Tanzimat Edebiyatı Kürsüsüne önce okutman, daha sonra asistan olarak tayin edildi. 1953'te “Türk Halk Şiirinde Tabiat" konulu teziyle doktorasını tamamladı. 1954-1956 yılları arasında Paris'te Sorbonne Üniversitesi'nde mukayeseli edebiyat derslerini takip etti, aynı zamanda Bibliothèque Nationalede Türk edebiyatıyla ilgili yazmalar ve kaynaklar üzerinde çalıştı. 1959'da "Abdülhak Hâmid'de Makber'den Önce Ölüm Temi” adlı teziyle doçent oldu. 1971 yılında da Nâmık Kemalin Mektubları adlı çalışmasıyla profesörlüğe yükseltildi. 1984’te Yeni Türk Edebiyatı Anabilim Dalı başkanı, 1990'da Türk Dili ve Edebiyatı bölüm başkanı olan Ömer Faruk Akün, 1993 yılında yaş haddinden emekliye ayrıldı. 1983-2000 yılları arasında Atatürk Kültür, Dil ve Tarih Kurumu Bilim Kurulu üyeliğine seçildi. 1989 yllından itibaren de TDV İslâm Ansiklopedisi Bilim Kurulu’nda çalıştı. Türk kültürüne yaptığı hizmet ve katkılarından dolayı 2005 yılında Türk Kültürüne Hizmet Vakfı tarafından kendisine "Şükran ödülü” verildi. Uzunca bir hastalık dönemini müteakip 2 Mayıs 2016'da vefat etti; cenazesi Karacaahmet Mezarlığı’na defnedildi.

İlim hayatında ve araştırmalarında Türkiye'de Türkoloji ilminin ve araştırmalarının kurucusu kabul edilen M. Fuad Köprülü’nün izinden giden ve onun metodunu benimseyen Ömer Faruk Akün, Fransızca, Almanca, İngilizce, Farsça ve Rusça dillerine hâkim olup uzun yıllar büyük emek harcayarak ortaya koyduğu bilimsel nitelikli çalışmalarının büyük bir kısmını 1949 yılından itibaren İstanbul Üniversitesi Edebiyat Fakültesỉnin yayını olan Türk Dili ve Edebiyatı Dergisi ile Türkiyat Mecmuası, Millî Eğitim Bakanlığı tarafından neşredilen İslâm Ansiklopedisi ve Türkiye Diyanet Vakfı'nca çıkarılan İslâm Ansiklopedisinnde yayımlamıştır. 
İlim çevrelerinde kılı kırk yararcasına araştırmacılığı ve kaynaklara hâkimiyetiyle tanınan Akün, üniversite hocası olarak vermiş olduğu yeni Türk edebiyatıyla ilgili dersler yanında dokuz yüksek lisans tezi ve dokuz tane de doktora tezi idare etmiştir.

Gerek derslerinde, gerekse çeşitli konferanslarında herhangi bir şekilde devir ayırımı yapmadan, Türk dili ve edebiyatı ile Türk tarihi ve Türk sanatını birbirinden ayrılmaz bir bütün olarak ele alan Akün, çalışmalarını bu çerçevede geniş bir sahayı kapsayacak şekilde gerçekleştirmiştir. Küçük yaşlarda başlayan okuma ve yeni şeyler öğrenme tutkusu hayatı boyunca doymak bilmez bir şekilde devam eden Akün, sayı bakımından az eser vermiş olmakla beraber, onun bütün çalışmaları Türkoloji sahasında çalışanlara örnek olacak ayrıntılara ve zenginliğe sahiptir.

Zaman zaman konferanslar vermek ya da bildiriler sunmak üzere yerli ve yabancı birçok ilmî toplantıya katılmış, üniversitelerdeki çeşitli tezler hakkında ayrıntılı raporlar hazırlamış, bu gibi faaliyetlerinde başkalarının dikkatini çekmeyen çeşitli hata, eksiklik ve intihalleri açıklamak suretiyle ilmî hassasiyetini ortaya koymaktan da geri kalmamıştır.

Hocayı yakından tanıyanlar, onun çalışma tarzını bilenler, yazdıklarını dikkatle okuyanlar, onun kılı kırk yaran, kendisinden başka kimseye benzemeyen farklı bir ilmî kişiliğe sahip olduğunu da bilirler. Yıllarca değişik çevrelerden gelen taleplere rağmen hocanın her biri müstakil bir monografi mahiyetindeki makale ve ansiklopedi maddelerini kitap haline getirmemesini, mükemmellik endișesinden ileri gelen, kısa sürede el çabukluğuyla ve para kazanmak için bir şeyler yapmaya kalkanlara karşı gerçek anlamda ilmî çalışmanın nasıl olması gerektiğini gösteren bir davranış olarak görmek icap eder.

Hocaya göre hangi sahada olursa olsun ciddi anlamda araştırmacılık, her şeyden önce büyük bir sabır, geniş bir tecessüs, ilmî disiplin ve büyük bir bilgi birikimi gerektirmektedir. 1980’li ylllarda hocayla “mükemmel bir Türk edebiyatı tarihi" yazılıp yazılamayacağı konusunda yapılan bir mülâkatta, hoca, Türkiye’deki kütüphanelerin gerektiği şekilde iyi çalışmadığı, Türk edebiyatıyla ilgili yurt dışındaki eserlere ulaşmanın güçlüğü, kaynak yetersizliği gibi bugün hâlâ geçerliğini koruyan birtakım engelleri sıraladıktan sonra, asıl şu noktaya gelmişti: Edebî şahsiyetler, edebî eserler ve çeşitli edebî dönemlerle ilgili ciddi monografilerin yokluğu ve kaynak mahiyetindeki eserlerin güvenilir neşirlerinin yapılmamış olduğu. Hocanın, kültür hayatımızda ciddi bir tenkit mecmuasına duyulan ihtiyacı sık sık gündeme getirmesi de, doğrudan doğruya bununla ilgili olmalıdır. Hocanın yazmış olduğu gerek makale, ge- 
rekse ansiklopedi maddelerinin sadece bibliyografyalarını gözden geçirmek bile, onun ilmî hassasiyetini gösteren önemli bir husustur.

Hocayı yakından tanıyanlar, onun çok erken yaşlarda sahasıyla ilgili her türden kitap toplamaya başladığını ve oldukça zengin bir kütüphaneye sahip olduğunu bilirler. Kitapla haşır neşir olan ve eskilerin "bibliyofil” dedikleri türden kitap tutkunlarında görülen bir özellik hocada da mevcuttur: Gerek evinde gerekse çalışma odasında artık kitap koyacak yer kalmadığı halde, hoca hastalanıncaya kadar sahasıyla ilgili yeni neşriyatı takip etmeye çalışmış, bunun için de hatırı sayılır miktarda paralar harcamıştır. Hocanın telakkisine göre, özel veya genel kütüphanelerde asla lüzumsuz bir şey bulunmaz; mükerrer de olsa onun bir sebebi vardır; tek bir yaprak parçası bile gün gelir birilerinin işine yarayabilir. Bunun için kütüphanenin tasfiyesi diye bir şey söz konusu değildir.

Ömer Faruk Akün'ün ilim âleminde ses getiren ve konuyla ilgili çeşitli bilimsel çalışmalarda sıklıkla kaynak olarak gösterilen, "Abdülhak Hâmid’in 'Merkad-i Fâtih'i Ziyaret' Manzumesi ve İçindeki Görüşler”, "Şinâsi’nin Bugüne Kadar Ele Geçmeyen Fatin Tezkiresi Baskısı", "Şinâsi’nin Fatin Tezkiresi Baskısındaki Yeni Biyografik Bilgiler", "Nâmık Kemal'in Kitap Hâlindeki Eserlerinin İlk Neşirleri”, "Abdülhak Hâmid’in Basılı Eserleri Hakkında Yeni Bilgiler", "Nâmık Kemal-Süleyman Paşa Mektuplaşması", "La Marseillaise'in Türkçe’de En Eski Manzum Tercümesi” "Tanzimat Edebiyatı Tabiri Ne Dereceye Kadar Doğrudur?” ve "Osmanlı Tarihi Karşısında Yahya Kemal’in Şiiri” adlı ve her biri küçük birer kitap çapındaki makaleleri hâlâ önemini koruyan sağlam bilgiler ihtiva etmektedir. Aynı şekilde eski ve yeni İslâm Ansiklopedisi'nde yayımlanan "Nâmık Kemal”, "Nergisî", "Şemseddin Sâmi”, "Şinâsi”, "Ahmed Vefik Paşa”, "Âlî”, "Bianchi”, "Bursalı Mehmed Tâhir”, "Çaylak Tevfik”, "Fatin Efendi”, “M. Fuad Köprülü”, "Gölpınarlı", “Gülnar Hanım”, “Hayrullah Efendi”, “Hoca Tahsin”, “İbnülemin Mahmud Kemal”, "Kâşgarlı Mahmud”, “Kilisli Rifat" ve "Koçi Bey" gibi büyük bir vukufla kaleme alınan maddeleri ise henüz kitaplaşmamıştır.

Ömer Faruk Akün'ün kitap halinde basılan çalışmaları şunlardır: Nâmık Kemal'in Mektubları (İstanbul: İstanbul Üniversitesi Edebiyat Fakültesi, 1972), Türk Dili Karşısında Türk Münevveri (İstanbul: Kubbealtı Neşriyatı, 1982), Divan Edebiyatı (İstanbul: İSAM Yayınları, 2013).

Abdullah Uçman

(Prof. Dr., Mimar Sinan Üniversitesi

Fen Edebiyat Fakültesi) 